\title{
Winter wheat growing in Ukraine: ecological assessment of technolo- gies by the influence on soil fertility
}

\author{
Valeriia BONDAR ${ }^{1,2}$, Nataliia MAKARENKO ${ }^{1}$
}

Winter wheat growing in Ukraine: ecological assessment of technologies by the influence on soil fertility

Abstract: Modern technologies of winter wheat growing need to be improved taking into account the results of ecological evaluation of their impact on soil fertility indices. We aimed to assess the technologies of winter wheat growing in different soil and climatic conditions of Ukraine by their influence on soil fertility. It is known that in order to estimate ecological safety of crop growing technologies, it is advisable to use a method based on identifying negative impacts on soil fertility. We propose the group of deviation values from the optimum as follows: (i) strong, which leads to an unsatisfactory ecological condition (>50\%), (ii) average that provides a satisfactory state ( $>25 \%$, but $<50 \%$ ), (iii) moderate, which provides a normal state $(\leq 10 \%$, but $<25 \%)$, (iv) absent, an optimal condition is provided $(<10 \%)$.

It is revealed that technologies of winter wheat growing in the conditions of Polissya, Forest-steppe and Steppe Zones of Ukraine can have a negative influence on potassium regime in soils, the influence by intensity can vary from moderate to strong. In Polissya and Forest-steppe, winter wheat growing can lead to deterioration of soil $\mathrm{pH}$ status. In Steppe, along with the potassium regime, the technologies can negatively influence soil nitrogen status and the effect may be characterized as strong.

Key words: ecological assessment; growing technology; limiting factors; soil fertility
Received December 12, 2018; accepted December 27, 2019. Delo je prispelo 12. decembra 2018, sprejeto 27. decembra 2019.

Pridelava ozimne pšenice v Ukrajini: ekološka ocena tehnologij glede na vplive na rodovitnost tal

Izvleček: Moderne tehnologije pridelave ozimne pšenice je potrebno izboljšati glede na ekološko ovrednotenje njihovega vpliva na indekse rodovitnosti tal. Namen raziskave je bil oceniti tehnologije pridelave ozimne pšenice na različnih tleh in klimatskih razmerah Ukrajine po njihovem vplivu na rodovitnost tal. Ugotovljeno je bilo, da je za oceno ekološke varnosti pridelave poljščin priporočljivo uporabiti metode, ki temeljijo na prepoznavanju negativnih učinkov na rodovitnost tal. Predlagamo naslednje skupine glede na odstopanja od optimalnega stanja: (i) močno odstopanje, ki vodi v nezadovoljive ekološke razmere (> $50 \%$ ), (ii) povprečno odstopanje, ki daje zadovoljivo stanje (> $25 \%$, a manj kot $50 \%$ ), (iii) zmerno odstopanje, ki daje normalno stanje ( $\leq 10 \%$, a manj kot $25 \%$ ), (iv) odstopanja ni, optimalno stanje (<10\%).

Ugotovljeno je bilo, da lahko imajo tehnologije pridelave ozimne pšenice v razmerah con polesja (Polissya), lesostepe (Forest-steppe) in stepe (Steppe) v Ukrajini negativni vpliv na režim kalija $\mathrm{v}$ tleh, jakost vpliva se spreminja od zmerne do močne. $\mathrm{V}$ polesju in lesostepi lahko pridelava ozimne pšenice vodi do poslapšanja $\mathrm{pH}$ tal. $\mathrm{V}$ stepi lahko tehnologije ob vplivu na režim kalija še močno negativno vplivajo na status dušika v tleh.

Ključne besede: ekološko ovrednotenje; tehnologija pridelave; omejujoči dejavniki; rodovitnost tal

1 National University of Life and Environmental Sciences of Ukraine, Faculty of Plant Protection, Biotechnology and Ecology, General Ecology and Safety Department, Kyiv, Ukraine

2 Corresponding author, e-mail: lera_bond@email.ua 


\section{INTRODUCTION}

At the International Congress on Environmental Issues in Agriculture (Lefebvre et al., 2005) where the most important issues of modern agrotechnologies were discussed, it was stated that their ecological safety is one of the main requirements nowadays. It has been shown by researches (Davidson, 2000; Arshad and Martin, 2002; Țenu et al., 2009; Killebrew and Wolff, 2010; Makarenko and Bondar, 2012) that it is impossible to identify environmental risks and to develop technologies that would meet the modern environmental standards without studying the mechanisms of negative influence of agrotechnical methods of crops growing on ecosystem components (Karlen et al., 2003; Killebrew and Wolff, 2010; Makarenko and Bondar, 2013). Winter wheat - is one of the leading crops for Ukraine. This crop is grown on an area of 6.4 million hectares and occupies about $37-40 \%$ in the structure of crops (according to the Ministry of Agrarian Policy of Ukraine, 2018).

In spite of its role as a major food in Eastern Europe (Petrenko et al., 2017) wheat is growing by technologies that causes environmentally negative impact. Thus, soil tillage, application of pesticides, mineral fertilizers, growth regulators, which can lead to violation of natural processes in the soil system and to soil degradation (Puskás and Farsang, 2009; Killebrew and Wolff, 2010; Mueller et al., 2012).

Baliuk and Medvediev pointed out that soil degradation is a result of maintaining old technologies in Ukrainian agriculture (Baliuk et al., 2012; Ukraine: Soil fertility to strengthen climate resilience. Preliminary assessment of the potential benefits of conservation agri- culture. 2014). Researches stated that pesticides application leads to soil and terrestrial ecosystems missfunction (Wasim et al., 2009). Application of agrochemicals violating the optimal doses, with expired dates, inappropriate proportions of nutrient elements will - decrease the effective and potential soil fertility, pollute natural water resources by toxicants and reduce the quality of agricultural products (Shang et al., 2019). Taking into account that the vast majority of agrochemicals are recycled products of industrial wastes. For instance, low enriched agro-ores have a high probability of impact on living organisms and ecosystems due to the presence of impurities of heavy metals, radionuclides, organic and inorganic substances (Hazrat et al., 2019). Therefore, the study of the influence of wheat growing technologies on the soil conditions of agroecosystems is of high importance from scientific and practical points of view.

The main purpose of the study was to identify (1) the negative processes in the soils of agroecosystems of different climatic zones of Ukraine for winter wheat cultivation; (2) the implementation of environmental regulation of the effects of winter wheat cultivation technology on the soils in agroecosystems; (3) application of the obtained results for the development of recommendations for winter wheat cultivation in the conditions of Ukraine.

\section{MATERIALS AND METHODS}

\subsection{SITE DESCRIPTION}

The research was carried out within the framework of scientific and technical program of National Acade-

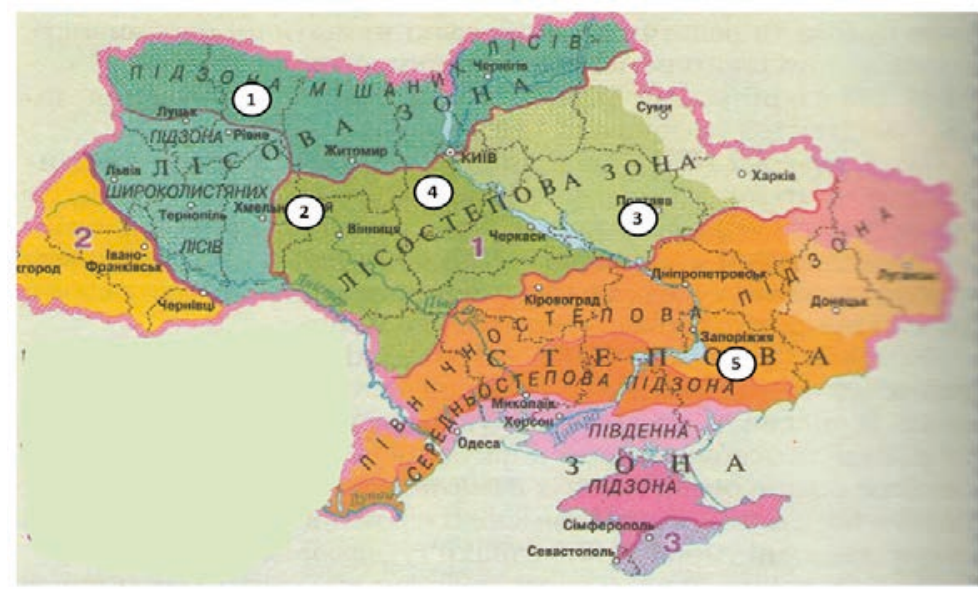

Figure 1: Mapping scheme of long-term field experiments location in various soil-climatic zones of Ukraine: 1 - Rivne SARS, 2 - Khmelnytskyi SARS, 3 - Poltava Institute AIP named after M. Vavilov, 4 - SS NULES of Ukraine "Agronomic Research Station", 5 - Zaporizhzhya RS IOS NAAS. 
Table 1: Characteristic of technologies of winter wheat growing in different soil-climatic zones of Ukraine

\begin{tabular}{|c|c|}
\hline Parameter & Characteristic of the parameter \\
\hline \multicolumn{2}{|c|}{ Poltava Institute AIP named after M. Vavilov } \\
\hline Soil type & chernozem typical low-humus heavy loamy \\
\hline Soil tillage & surface tillage, plowing, pre-sowing cultivation \\
\hline $\begin{array}{l}\text { Variety / biological yield } \\
\text { Planting rate / method } \\
\text { Preceding crop }\end{array}$ & $\begin{array}{l}\text { Kosoch / } 5.93 \mathrm{t} \mathrm{ha}^{-1} \\
200 \mathrm{~kg} \mathrm{ha}^{-1} / \text { conventional sowing } \\
\text { pea }\end{array}$ \\
\hline Fertilization system & organic fertilizers (manure $10 \mathrm{t} \mathrm{ha}^{-1}$ ) and mineral fertilizers $\mathrm{N}_{52} \mathrm{P}_{52} \mathrm{~K}_{52}$ \\
\hline Protection system & recommended for this soil-climatic zone \\
\hline \multicolumn{2}{|l|}{ Khmelnytskyi SARS } \\
\hline Soil type & $\begin{array}{l}\text { chernozem podzolized slightly eroded medium loamy with deep ground- } \\
\text { water occurrence }\end{array}$ \\
\hline Soil tillage & plowing, disking \\
\hline $\begin{array}{l}\text { Variety / biological yield } \\
\text { Planting rate / method } \\
\text { Preceding crop }\end{array}$ & $\begin{array}{l}\text { Astet / } 6.85 \mathrm{tha}^{-1} \\
135 \mathrm{~kg} \mathrm{ha}^{-1} / \text { conventional sowing } \\
\text { pea }\end{array}$ \\
\hline Fertilization system & $\begin{array}{l}\text { organic fertilizers (manure } 16 \mathrm{tha}^{-1} \text { and } 8 \mathrm{tha}^{-1} \text { ) and mineral fertilizers } \\
\left(\mathrm{N}_{116} \mathrm{P}_{60} \mathrm{~K}_{120} \text { and } \mathrm{N}_{55} \mathrm{P}_{30} \mathrm{~K}_{60}\right)\end{array}$ \\
\hline Protection system & recommended for this soil-climatic zone \\
\hline \multicolumn{2}{|c|}{ SS NULES of Ukraine "Agronomic Research Station" } \\
\hline Soil type & chernozem typical low-humus medium loamy \\
\hline Soil tillage & surface tillage, plowing, pre-sowing cultivation \\
\hline $\begin{array}{l}\text { Variety / biological yield } \\
\text { Planting rate / method } \\
\text { Preceding crop }\end{array}$ & $\begin{array}{l}\text { Natsionalna / } 6 \mathrm{t} \mathrm{ha}^{-1} \\
150 \mathrm{~kg} \mathrm{ha}^{-1} / \text { conventional sowing } \\
\text { pea }\end{array}$ \\
\hline Fertilization system & mineral fertilizers $\mathrm{N}_{60} \mathrm{P}_{60} \mathrm{~K}_{60}$ \\
\hline Protection system & recommended for this soil-climatic zone \\
\hline \multicolumn{2}{|l|}{ Rivne SARS } \\
\hline Soil type & dark grey podzolized \\
\hline Soil tillage & surface tillage, plowing, pre-sowing cultivation \\
\hline $\begin{array}{l}\text { Variety / biological yield } \\
\text { Planting rate / method } \\
\text { Preceding crop }\end{array}$ & $\begin{array}{l}\text { Poliska } 90 / 6.5 \mathrm{t} \mathrm{ha}^{-1} \\
145 \mathrm{~kg} \mathrm{ha}^{-1} / \text { conventional sowing } \\
\text { pea }\end{array}$ \\
\hline Fertilization system & $\begin{array}{l}\text { mineral fertilizers } \mathrm{N}_{90} \mathrm{P}_{60} \mathrm{~K}_{60} \text {, organic (manure } 10 \mathrm{tha}^{-1} \text { ), organic-mineral } \\
\text { (straw + green manure }+\mathrm{N}_{90} \mathrm{P}_{60} \mathrm{~K}_{60}\end{array}$ \\
\hline Protection system & recommended for this soil-climatic zone \\
\hline \multicolumn{2}{|c|}{ Zaporizhzhya RS IOS NAAS } \\
\hline Soil type & chernozem ordinary low-humus \\
\hline Soil tillage & basic cultivation, plowing, pre-sowing cultivation \\
\hline $\begin{array}{l}\text { Variety / biological yield } \\
\text { Planting rate / method } \\
\text { Preceding crop }\end{array}$ & $\begin{array}{l}\text { Dalnytska / } 7 \mathrm{t} \mathrm{ha}^{-1} \\
200 \mathrm{~kg} \mathrm{ha}^{-1} / \text { conventional sowing } \\
\text { black fallow }\end{array}$ \\
\hline Fertilization system & $\begin{array}{l}\text { mineral fertilizers in the following doses: } \mathrm{N}_{75} \mathrm{P}_{50} \mathrm{~K}_{25}, \mathrm{~N}_{50} \mathrm{P}_{50} \mathrm{~K}_{50}, \mathrm{~N}_{15} \mathrm{P}_{10} \mathrm{~K}_{5} \text {, } \\
\text { organic fertilizers: semi-decomposed manure } 5.7 \mathrm{tha}^{-1}\end{array}$ \\
\hline Protection system & recommended for this soil-climatic zone \\
\hline
\end{tabular}


my of Agrarian Sciences of Ukraine (NAAS) "Scientific and practical substantiation of sustainable development of agroecosystems in Ukraine", which envisaged integrated research of crops growing technologies in various soil and climatic zones of Ukraine. The following institutions were involved in this study: Institute of Agroecology and Environmental management of $\mathrm{Na}$ tional Academy of Agrarian Sciences (NAAS, $48^{\circ} 18^{\prime} \mathrm{N}$, $\left.25^{\circ} 56^{\prime} \mathrm{E}\right)$; Rivne State Agricultural Research Station (Rivne SARS, $50^{\circ} 37^{\prime} \mathrm{N}, 26^{\circ} 15^{\prime} \mathrm{E}$ ); Khmelnytskyi State Agricultural Research Station (Khmelnytskyi SARS, $\left.49^{\circ} 25^{\prime} \mathrm{N}, 27^{\circ} 0^{\prime} \mathrm{E}\right)$; Poltava Institute of agro-industrial production (Poltava Institute AIP, 49 $35^{\prime} \mathrm{N}, 34^{\circ} 34^{\prime} \mathrm{E}$ ) named after M. Vavilov; Zaporizhzhya Agricultural Research Station of the Institute of Oilseeds (Zaporizhzhya RS IOS NAAS, $47^{\circ} 50^{\prime} \mathrm{N}, 35^{\circ} 10^{\prime} \mathrm{E}$ ); Separated subdivision of National University of Life and Environmental Sciences of Ukraine (SS NULES of Ukraine, $50^{\circ} 10^{\prime} \mathrm{N}, 30^{\circ} 19^{\prime} \mathrm{E}$ ) “Agronomic Research Station”. The research was conducted during 2007 - 2018 years in the conditions of long-term field experiments (established more than 20 years ago) located in Polissya, ForestSteppe and Steppe regions of Ukraine (Figure 1).

\subsection{METHODOLOGY OF TECHNOLOGIES AS- SESSMENT}

The basic technology (BT) of winter wheat growing which envisaged soil tillage depending on its type, selection of regional variety, seed rates and method of sowing, system of plant protection. In addition, technologies with application of mineral and organic fertilizers in various combinations were studied, taking into account soil-climatic conditions of the of the experiments location (Table 1).

The basic agrochemical parameters of the soil were determined according to standardized methods: $\mathrm{pH}_{\mathrm{KCl}}$ - by potentiometric method (displacement of exchange ions $\mathrm{H}^{+}$and $\mathrm{Al}^{3+} 1 \mathrm{~N} \mathrm{KCl}(\mathrm{pH}=5.56)$ ratio of soil to solution was $1: 2.5$ ), nitrogen content that is easily hydrolysed - by Cornflind (the method is based on alkaline hydrolysis of organic nitrogen-containing compounds of soil under the action of $1 \mathrm{~N} \mathrm{NaOH}$ for two days at $260{ }^{\circ} \mathrm{C}$. The released ammonia is absorbed by boric acid and is determined by titration with sulfuric acid), content of exchangeable potassium and labile phosphorus - according to the modified Machigin method (the method is based on the removal of mobile compounds of phosphorus and potassium from the soil with a $1 \%$ $\left(\left(\mathrm{NH}_{4}\right)_{2} \mathrm{CO}_{3}\right),(\mathrm{pH} 9.0)$ at the soil:solution ratio $1: 20$ and a temperature of $25 \pm 2^{\circ} \mathrm{C}$. The soil suspension was shaken for - 5 minutes and than, insulating the soil in solution - 20 hours. Before determining the phosphorus, the colored soil extraction was discolored with activated carbon. Phosphorus was determined calorimetrically after ammonium molibdate addition. Potassium was determined by flame photometry. Soil organic matter (SOM) was determined - by Tyurin method (the method is based on the oxidation of organic carbon to $\mathrm{CO}_{2}$ by a solution of potassium bichromate and sulfuric acid, the excess of which is titrated with Mora salt).

\subsection{STATISTICAL ANALYSIS}

Data are presented as mean values of four replicates and standard deviations. The significance of the experimental data was estimated by the analysis of variance (two-factor ANOVA) following calculation of the least significant difference $\mathrm{LSD}_{05}$.

\section{RESULTS AND DISCUSSION}

Following the concept of limiting factors, a method for evaluating the technology was proposed the intensity of its negative influence on soil fertility indices:

strong influence, which leads to an unsatisfactory ecological state of components of agroecosystems or individual processes that occur in them (the deviation from the optimum in the direction of deterioration is more than $50 \%$ );

medium influence that provides a satisfactory state of components of agroecosystems or individual processes that occur in them (the deviation from the optimum in the direction of deterioration is greater than $25 \%$ but does not exceed $50 \%$ );

moderate influence, which ensures a normal state of components of agroecosystems or individual processes that occur in them (the deviation from optimum in the direction of deterioration more than $10 \%$ but not exceeding $25 \%$ );

no influence, which ensures an optimal state of components of agroecosystems or individual processes that occur in them (the deviation from the optimum in the direction of deterioration does not exceed $10 \%$ ) is provided.

The optimal soil parameters by fertility indices were determined according to DSTU 4362: 2004 "Soil quality. Soil fertility indices". The optimal parameters of fertility indexes are presented in Table 2.

According to the results of our research, the technologies of winter wheat growing in different soil and climatic conditions of Ukraine influenced the formation of edaphic soil parameters of the agroecosystem, 
Table 2: The range of soil parameters and respective ecological state

\begin{tabular}{|c|c|c|c|c|c|}
\hline \multirow[t]{2}{*}{ Ecological state } & \multirow[t]{2}{*}{$\begin{array}{l}\text { Nitrogen that is easily } \\
\text { hydrolyzed }\end{array}$} & \multirow{2}{*}{$\begin{array}{c}\text { Labile phosphorus } \\
\qquad \mathrm{mg} \mathrm{kg}^{-1}\end{array}$} & \multirow[t]{2}{*}{$\begin{array}{l}\text { Exchangeable potas- } \\
\text { sium }\end{array}$} & \multirow{2}{*}{$\mathrm{pH}_{\mathrm{KCl}}$} & \multirow[t]{2}{*}{ SOM, \% } \\
\hline & & & & & \\
\hline \multicolumn{6}{|c|}{ chernozem typical low-humus heavy loamy } \\
\hline Standard & $35-45$ & $45-60$ & $300-400$ & $6.3-7.0$ & $4.5-5.7$ \\
\hline Optimal & $32-34$ & $41-44$ & $270-299$ & $5.7-6.2$ & $4.1-4.4$ \\
\hline Normal & $27-33$ & $34-43$ & $228-269$ & $4.8-5.6$ & $3.4-4.0$ \\
\hline Satisfactory & $18-26$ & $23-33$ & $150-227$ & $3.2-4.7$ & $2.3-3.3$ \\
\hline Unsatisfactory & $<18$ & $<23$ & $<150$ & $<3.2$ & $<2.3$ \\
\hline \multicolumn{6}{|c|}{ chernozem podzolized medium loamy slightly eroded } \\
\hline Standard & $35-45$ & $150-200$ & $120-170$ & $5.7-6.4$ & $2.8-4.2$ \\
\hline Optimal & $34-32$ & $135-149$ & $108-119$ & $5.1-5.6$ & $2.5-2.7$ \\
\hline Normal & $33-27$ & $113-134$ & $90-107$ & $4.3-5.5$ & $2.1-2.4$ \\
\hline Satisfactory & $18-26$ & $75-112$ & $59-89$ & $2.9-4.4$ & $1.3-2.0$ \\
\hline Unsatisfactory & $<18$ & $<75$ & $<60$ & $<2.9$ & $<1.4$ \\
\hline \multicolumn{6}{|c|}{ chernozem typical low-humus medium loamy } \\
\hline Standard & $35-45$ & $45-60$ & $300-400$ & $6.0-6.8$ & $3.5-5.0$ \\
\hline Optimal & $34-32$ & $41-44$ & $270-299$ & $5.4-5.9$ & $3.2-3.4$ \\
\hline Normal & $33-27$ & $34-40$ & $228-269$ & $4.5-5.3$ & $2.6-3.1$ \\
\hline Satisfactory & $18-26$ & $22-33$ & $150-227$ & $3.0-4.4$ & $1.8-2.5$ \\
\hline Unsatisfactory & $<18$ & $<23$ & $<150$ & $<3.0$ & $<1.8$ \\
\hline \multicolumn{6}{|c|}{ dark grey podzolized } \\
\hline Standard & $35-45$ & $150-200$ & $170-220$ & $5.3-6.0$ & $1.6-2.6$ \\
\hline Optimal & $34-32$ & $135-149$ & $153-169$ & $4.8-5.2$ & $1.4-1.5$ \\
\hline Normal & $33-27$ & $113-134$ & $128-152$ & $4.0-4.7$ & $1.2-1.3$ \\
\hline Satisfactory & $18-26$ & $75-112$ & $85-127$ & $2.7-3.9$ & $0.8-1.1$ \\
\hline Unsatisfactory & $<18$ & $<75$ & $<85$ & $<2.7$ & $<0.8$ \\
\hline \multicolumn{6}{|c|}{ chernozem ordinary low-humus } \\
\hline Standard & $35-45$ & $45-60$ & $300-400$ & $6.8-7.6$ & $3.2-5.3$ \\
\hline Optimal & $34-32$ & $41-44$ & $270-299$ & $6.1-6.7$ & $2.9-3.1$ \\
\hline Normal & $33-27$ & $34-43$ & $228-269$ & $5.1-6.0$ & $2.4-2.8$ \\
\hline Satisfactory & $18-26$ & $23-33$ & $150-227$ & $3.4-5.0$ & $1.6-2.3$ \\
\hline Unsatisfactory & $<18$ & $<23$ & $<150$ & $<3.4$ & $<1.6$ \\
\hline
\end{tabular}

and, consequently, the conditions of plant nutrition. The soil fertility indicators by long-term influence of the winter wheat growing technologies are presented in Table 3.

A comparison of the soil actual parameters with the optimum level allowed to establish general patterns of changes occurring in the soil component of agroecosystems, and to identify the main negative effects of technologies (Table 4):

nitrogen regime: there was no negative influence of the technologies on the content of nitrogen forms in typical, podzolized and dark gray podzolized soils. The exception was chernozem, in which the technology led to the decrease of nitrogen content. The effect varied from medium to strong. Negative phenomenon was not eliminated even with nitrogen application at the rates $\mathrm{N}_{15}-\mathrm{N}_{75} \mathrm{~kg} \mathrm{ha}^{-1}$;

- phosphorus regime: the technologies provided optimal soil parameters by the content of phosphorus form in all soils. The exception was observed in chernozem podzolized, where the basic technology implementation led to the depletion of mobile phosphorus 
Table 3: Indicators of soil fertility for different technologies of winter wheat growing

\begin{tabular}{|c|c|c|c|c|c|}
\hline \multirow{3}{*}{ Technology } & \multicolumn{5}{|c|}{ Indicators of soil fertility } \\
\hline & \multirow[t]{2}{*}{$\begin{array}{l}\text { Nitrogen that is eas- } \\
\text { ily hydrolyzed }\end{array}$} & \multirow{2}{*}{$\begin{array}{c}\text { Labile phosphorus } \\
\mathrm{mg} \mathrm{kg}^{-1}\end{array}$} & \multirow[t]{2}{*}{$\begin{array}{l}\text { Exchangeable potas- } \\
\text { sium }\end{array}$} & \multirow[t]{2}{*}{$\mathrm{pH}_{\mathrm{KCl}}$} & \multirow[t]{2}{*}{ SOM, \% } \\
\hline & & & & & \\
\hline \multicolumn{6}{|c|}{ chernozem typical low-humus heavy loamy } \\
\hline BT & $102 \pm 1.70$ & $78 \pm 3.40$ & $65 \pm 1.63$ & $4.8 \pm 0.09$ & $5.4 \pm 0.16$ \\
\hline $\mathrm{BT}+$ manure $10 \mathrm{t} \mathrm{ha}^{-1}$ & $109 \pm 2.49$ & $92 \pm 0.94$ & $103 \pm 1.41$ & $5.0 \pm 0.09$ & $5.5 \pm 0.22$ \\
\hline $\mathrm{BT}+\mathrm{N}_{52} \mathrm{P}_{52} \mathrm{~K}_{52}+$ straw $+\mathrm{N}_{10}$ & $112 \pm 1.25$ & $132 \pm 2.83$ & $112 \pm 0.82$ & $5.5 \pm 0.21$ & $5.3 \pm 0.05$ \\
\hline $\mathrm{BT}+$ manure $10 \mathrm{tha}^{-1}+\mathrm{N}_{52} \mathrm{P}_{52} \mathrm{~K}_{52}$ & $119 \pm 0.94$ & $170 \pm 2.62$ & $153 \pm 3.09$ & $5.2 \pm 0.09$ & $5.5 \pm 0.05$ \\
\hline $\mathrm{LSD}_{0.05}$ & 12.11 & 3.37 & 6.67 & 0.18 & 0.21 \\
\hline \multicolumn{6}{|c|}{ chernozem podzolized medium loamy slightly eroded } \\
\hline BT & $101.5 \pm 0.26$ & $78 \pm 0.47$ & $72 \pm 0.94$ & $5.0 \pm 0.05$ & $3.1 \pm 0.05$ \\
\hline $\mathrm{BT}+\mathrm{N}_{116} \mathrm{P}_{60} \mathrm{~K}_{120}$ & $119.0 \pm 1.89$ & $146 \pm 0.94$ & $106 \pm 0.29$ & $3.5 \pm 0.03$ & $5.0 \pm 0.22$ \\
\hline $\mathrm{BT}+$ manure $16 \mathrm{tha}^{-1}$ & $105.6 \pm 0.19$ & $246 \pm 2.83$ & $235 \pm 0.31$ & $3.8 \pm 0.09$ & $6.3 \pm 0.16$ \\
\hline $\mathrm{BT}+$ manure $8 \mathrm{tha}^{-1}+\mathrm{N}_{55} \mathrm{P}_{30} \mathrm{~K}_{60}$ & $103.3 \pm 0.14$ & $490 \pm 0.47$ & $160 \pm 0.12$ & $3.5 \pm 0.05$ & $6.4 \pm 0.09$ \\
\hline $\mathrm{LSD}_{0.05}$ & 22.12 & 14.05 & 17.23 & 0.86 & 1.16 \\
\hline \multicolumn{6}{|c|}{ chernozem typical low-humus medium loamy } \\
\hline BT & $84.2 \pm 0.08$ & $67 \pm 0.38$ & $230 \pm 0.45$ & $7.7 \pm 0.02$ & $2.9 \pm 0.05$ \\
\hline $\mathrm{BT}+\mathrm{N}_{60} \mathrm{P}_{60} \mathrm{~K}_{60}$ & $94.5 \pm 0.37$ & $62 \pm 0.05$ & $240 \pm 0.37$ & $7.7 \pm 0.03$ & $3.2 \pm 0.09$ \\
\hline $\mathrm{LSD}_{0.05}$ & 4.67 & 1.16 & 8.04 & 0.14 & 0.57 \\
\hline \multicolumn{6}{|c|}{ dark grey podzolized } \\
\hline BT & $75.4 \pm 0.05$ & $165 \pm 0.12$ & $53 \pm 0.16$ & $4.9 \pm 0.09$ & $1.3 \pm 0.02$ \\
\hline $\mathrm{BT}+\mathrm{N}_{90} \mathrm{P}_{60} \mathrm{~K}_{60}$ & $87.5 \pm 0.16$ & $245 \pm 0.14$ & $65 \pm 0.21$ & $5.2 \pm 0.05$ & $1.5 \pm 0.04$ \\
\hline $\mathrm{BT}+$ manure $10 \mathrm{t} \mathrm{ha}^{-1}$ & $91.0 \pm 0.17$ & $295 \pm 0.08$ & $85 \pm 0.19$ & $5.1 \pm 0.16$ & $1.5 \pm 0.05$ \\
\hline $\begin{array}{l}\mathrm{BT}+\mathrm{N}_{90} \mathrm{P}_{60} \mathrm{~K}_{60}+\text { straw }+ \text { green } \\
\text { manures }\end{array}$ & $91.0 \pm 0.16$ & $340 \pm 0.09$ & $91 \pm 0.26$ & $5.6 \pm 0.16$ & $1.4 \pm 0.05$ \\
\hline $\mathrm{LSD}_{0.05}$ & 2.96 & 15.11 & 6.12 & 0.92 & 0.58 \\
\hline \multicolumn{6}{|c|}{ chernozem ordinary low-humus } \\
\hline BT & $9.8 \pm 0.09$ & $100 \pm 0.41$ & $150 \pm 0.16$ & $7.15 \pm 0.16$ & $3.9 \pm 0.02$ \\
\hline $\mathrm{BT}+\mathrm{N}_{75} \mathrm{P}_{50} \mathrm{~K}_{25}$ & $15.6 \pm 0.34$ & $243 \pm 0.17$ & $183 \pm 0.17$ & $7.00 \pm 0.05$ & $4.1 \pm 0.05$ \\
\hline $\mathrm{BT}+\mathrm{N}_{50} \mathrm{P}_{50} \mathrm{~K}_{50}$ & $22.3 \pm 0.17$ & $280 \pm 0.19$ & $205 \pm 0.21$ & $6.72 \pm 0.09$ & $3.8 \pm 0.02$ \\
\hline $\mathrm{BT}+\mathrm{N}_{15} \mathrm{P}_{10} \mathrm{~K}_{5}$ & $14.7 \pm 0.08$ & $199 \pm 0.47$ & $159 \pm 0.37$ & $6.98 \pm 0.16$ & $4.1 \pm 0.09$ \\
\hline $\mathrm{BT}+$ manure $5.7 \mathrm{t} \mathrm{ha}^{-1}$ & $11.4 \pm 0.19$ & $144 \pm 0.19$ & $219 \pm 0.19$ & $7.07 \pm 0.08$ & $3.8 \pm 0.05$ \\
\hline $\mathrm{LSD}_{0.05}$ & 3.82 & 22.14 & 20.10 & 3.57 & 2.63 \\
\hline
\end{tabular}

level and the influence of technology was characterized as strong;

potassium regime: there was a negative influence of the technologies on the content of exchangeable forms of potassium in all soil types, it varied from moderate to strong. The most dangerous impact of the technologies was recorded in dark gray podzolized soils (strong);

soil $\mathrm{pH}$ : the influence of technologies within the limits of the moderate and average in chernozem typical low-humus heavy-loamy and chernozem podzolized; in dark gray podzolized soil, the negative influence was observed only in the basic technology;

SOM content: technologies did not lead to negative changes in the SOM. The obtained results indicate the inappropriateness of using SOM status indicator as a diagnostic tool for assessing the influence of technologies on soil fertility.

Thus, it was established that in Polissya, Foreststeppe and Steppe of Ukraine the technologies of win- 
Table 4: Influence of the winter wheat growing technologies on soil fertility indicators

\begin{tabular}{|c|c|c|c|c|c|}
\hline \multirow[b]{2}{*}{ Technology } & \multicolumn{5}{|c|}{ Negative influence of technology on indicators of soil condition } \\
\hline & $\begin{array}{l}\text { Nitrogen that is } \\
\text { easily hydrolyzed }\end{array}$ & $\begin{array}{l}\text { Labile } \\
\text { phosphorus }\end{array}$ & $\begin{array}{l}\text { Exchangeable } \\
\text { potassium }\end{array}$ & $\mathrm{pH}_{\mathrm{KCl}}$ & SOM, $\%$ \\
\hline \multicolumn{6}{|c|}{ chernozem typical low-humus heavy loamy } \\
\hline BT & absent & absent & strong & moderate & absent \\
\hline $\mathrm{BT}+$ manure $10 \mathrm{t} \mathrm{ha}^{-1}$ & absent & absent & strong & moderate & absent \\
\hline $\mathrm{BT}+\mathrm{N}_{52} \mathrm{P}_{52} \mathrm{~K}_{52}+$ straw $+\mathrm{N}_{10}$ & absent & absent & strong & moderate & absent \\
\hline $\mathrm{BT}+$ manure $10 \mathrm{tha}^{-1}+\mathrm{N}_{52} \mathrm{P}_{52} \mathrm{~K}_{52}$ & absent & absent & strong & moderate & absent \\
\hline \multicolumn{6}{|c|}{ chernozem podzolized medium loamy slightly eroded } \\
\hline BT & absent & strong & strong & moderate & absent \\
\hline $\mathrm{BT}+\mathrm{N}_{116} \mathrm{P}_{60} \mathrm{~K}_{120}$ & absent & absent & moderate & medium & absent \\
\hline $\mathrm{BT}+$ manure $16 \mathrm{tha}^{-1}$ & absent & absent & absent & medium & absent \\
\hline $\mathrm{BT}+$ manure $8 \mathrm{tha}^{-1}+\mathrm{N}_{55} \mathrm{P}_{30} \mathrm{~K}_{60}$ & absent & absent & absent & medium & absent \\
\hline \multicolumn{6}{|c|}{ chernozem typical low-humus medium loamy } \\
\hline BT & absent & absent & moderate & absent & moderate \\
\hline $\mathrm{BT}+\mathrm{N}_{60} \mathrm{P}_{60} \mathrm{~K}_{60}$ & absent & absent & moderate & absent & absent \\
\hline \multicolumn{6}{|c|}{ dark grey podzolized } \\
\hline BT & absent & absent & strong & moderate & moderate \\
\hline $\mathrm{BT}+\mathrm{N}_{90} \mathrm{P}_{60} \mathrm{~K}_{60}$ & absent & absent & strong & absent & absent \\
\hline $\mathrm{BT}+$ manure $10 \mathrm{tha}^{-1}$ & absent & absent & strong & absent & absent \\
\hline $\mathrm{BT}+\mathrm{N}_{90} \mathrm{P}_{60} \mathrm{~K}_{60}+$ straw + green manures & absent & absent & strong & absent & absent \\
\hline \multicolumn{6}{|c|}{ chernozem ordinary low-humus } \\
\hline BT & strong & absent & medium & absent & moderate \\
\hline $\mathrm{BT}+\mathrm{N}_{75} \mathrm{P}_{50} \mathrm{~K}_{25}$ & strong & absent & medium & absent & absent \\
\hline $\mathrm{BT}+\mathrm{N}_{50} \mathrm{P}_{50} \mathrm{~K}_{50}$ & medium & absent & medium & absent & moderate \\
\hline $\mathrm{BT}+\mathrm{N}_{15} \mathrm{P}_{10} \mathrm{~K}_{5}$ & strong & absent & medium & absent & absent \\
\hline $\mathrm{BT}+$ manure $5.7 \mathrm{t} \mathrm{ha}^{-1}$ & strong & absent & medium & absent & moderate \\
\hline
\end{tabular}

ter wheat growing negatively affected potassium regime of soils: - there was a depletion of mobile potassium forms; in chernozem typical low-humus and chernozem podzolized medium-loamy winter wheat growing led to deterioration of the acid-base conditions of the soil - there were processes of acidification of the soil solution. In Steppe, along with potassium regime, the technology negatively affected nitrogen regime of the soil - there were observed processes of depletion of stocks of nitrogen compounds. It is possible to predict that the indicated negative phenomena in the soil led to a violation of the interconnections in the soil-plant system. To confirm this, the productivity of winter wheat cultivation under various technologies was investigated.

It is known that productivity, that is the ability of ecosystem to form biomass over a certain period of time on a certain area, is an integral indicator of its state. In agroecosystems, it was decided to determine productiv- ity of a main agricultural crop (a determinant). In our case, the determinant was winter wheat and, according to the level of its productivity, an assessment of the impact of technology on the agroecosystem was carried out. Potential productivity of a certain wheat variety was taken as a standard (etalon) since this indicator indicates the maximum possible biological potential the crop can use for the formation of biomass.

At the same time, in case of reduced wheat productivity relative to the standard, the limiting edaphic soil factors, that could negatively affect plant growth and development, were determined. In Forest-steppe zone based on Poltava Institute AIP named after $\mathrm{M}$. Vavilov winter wheat of the Kosoch variety was studied. The potential yield of this variety is $5.93 \mathrm{t} \mathrm{ha}^{-1}$. Climate of Poltava region is continental. The mean annual temperature is $+8.2^{\circ} \mathrm{C}$. The mean annual precipitation is $580-480 \mathrm{~mm}$. The productivity of wheat at the po- 


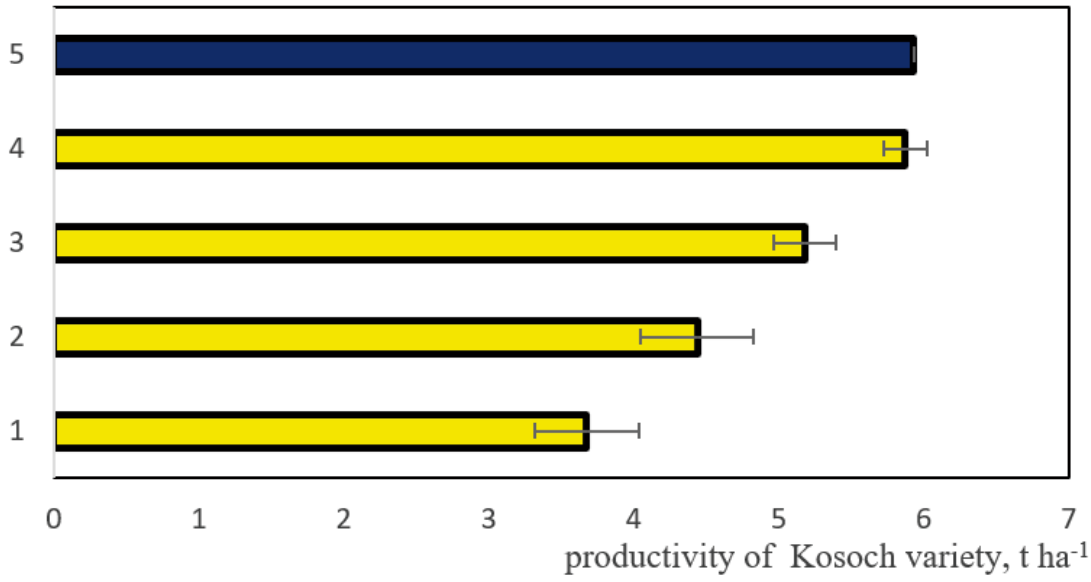

Figure 2: Influence of the technologies on productivity of winter wheat variety Kosoch (soil - chernozem typical low-humus heavy-loamy; 1. BT; 2. BT + manure $10 \mathrm{tha}^{-1} ; 3 . \mathrm{BT}+\mathrm{N}_{52} \mathrm{P}_{52} \mathrm{~K}_{52}+$ straw $+\mathrm{N}_{10} ; 4$. BT + manure $10 \mathrm{t} \mathrm{ha}^{-1}+\mathrm{N}_{52} \mathrm{P}_{52} \mathrm{~K}_{52} ; 5$. Standard)

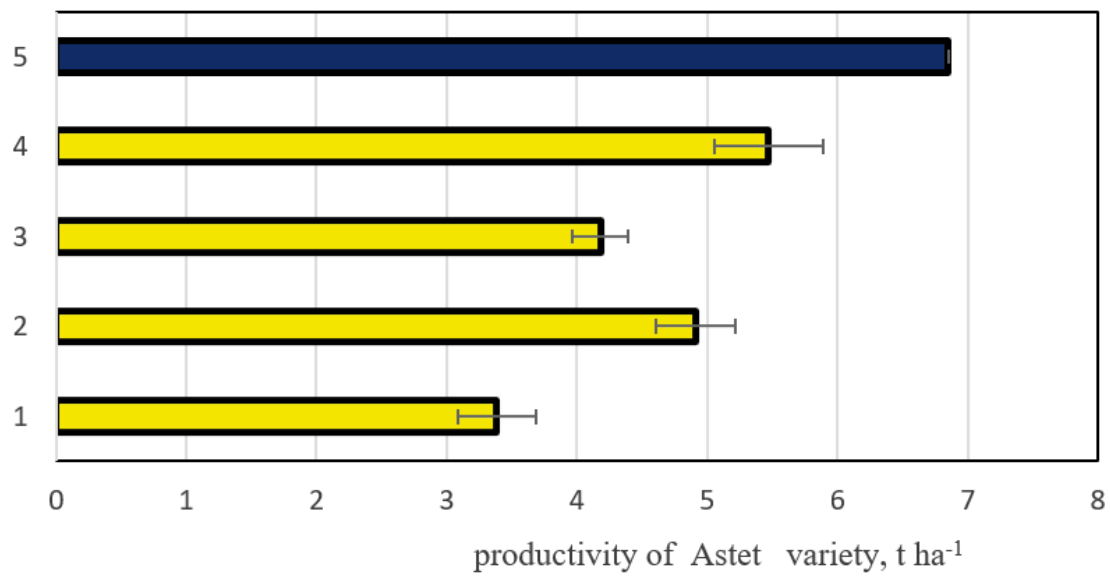

Figure 3: Influence of the technologies on productivity of winter wheat variety Astet (soil - chernozem podzolized medium loamy slightly eroded; 1 . BT; 2 . BT $+\mathrm{N}_{116} \mathrm{P}_{60} \mathrm{~K}_{120} ; 3$. BT + manure $16 \mathrm{tha}^{-1} ; 4$. $\mathrm{BT}+$ manure $8 \mathrm{t} \mathrm{ha}^{-1}+\mathrm{N}_{55} \mathrm{P}_{30} \mathrm{~K}_{60} ; 5$. Standard)

tential level was ensured by the technology with integrated mineral and organic fertilizer application $(\mathrm{BT}+$ $\mathrm{N}_{52} \mathrm{P}_{52} \mathrm{~K}_{52}+$ manure of $10 \mathrm{tha}^{-1}$ ). The basic technology, the technology with applied organic fertilizers did not allow achieving the standard level of crop productivity. The deviation from the standard was $26.4-35.5 \%$, that is, the negative impact of technology is estimated as medium (Figure 2). It can be assumed that one of the reasons for unsatisfactory growth and development of plants using these technologies was insufficient level of mobile potassium supply to plants. This effect was amplified by the discrepancy of the reaction of the soil environment with requirements of the crop.

In the conditions of Khmelnytskyi SARS (ForestSteppe zone), winter wheat of the Astet variety was studied, whose potential yield is $6.85 \mathrm{t} \mathrm{ha}^{-1}$. Climate of Khmelnytsky region is continental. The mean annual temperature is $+7.3^{\circ} \mathrm{C}$. The mean annual precipitation is $530-670 \mathrm{~mm}$. The basic technology, as well as the technologies of mineral fertilizers $\mathrm{BT}+\mathrm{N}_{116} \mathrm{P}_{60} \mathrm{~K}_{120}$, $\mathrm{BT}+$ manure of $16 \mathrm{t} \mathrm{ha}^{-1}$ application did not provide the optimal conditions for plant growth and development. The productivity level of wheat was 27.3-52.8 \% lower comparing the standard. The influence of the technologies on the state of agroecosystem by the level of wheat productivity can be estimated as strong and average (Figure 3). One of the reasons for this phenomenon could be the depletion of the mobile forms of soil phosphorus, potassium and the discrepancy of soil $\mathrm{pH}$ to requirements of the crop.

In the conditions of SS NULES of Ukraine "Agronomic Research Station" (Forest-Steppe zone) winter wheat of the Natsionalna variety was studied, the potential yield of which is $6 \mathrm{t} \mathrm{ha}^{-1}$. Climate of Kyiv re- 
3

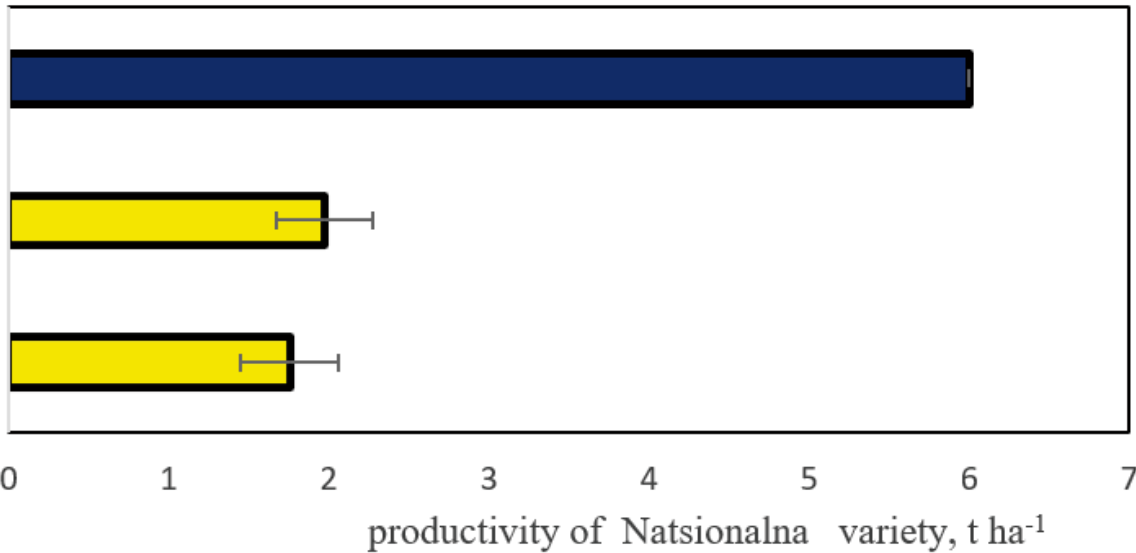

Figure 4: Influence of the technologies on productivity of winter wheat variety Natsionalna (soil - chernozem typical low-humus medium loamy; 1. BT; 2. BT $+\mathrm{N}_{60} \mathrm{P}_{60} \mathrm{~K}_{60} ; 3$. Standard) (Note: Averages in groups are significantly different from each other, ANOVA with Bonferroni correction, except of those, marked by ${ }^{\star} p<0.05$ )

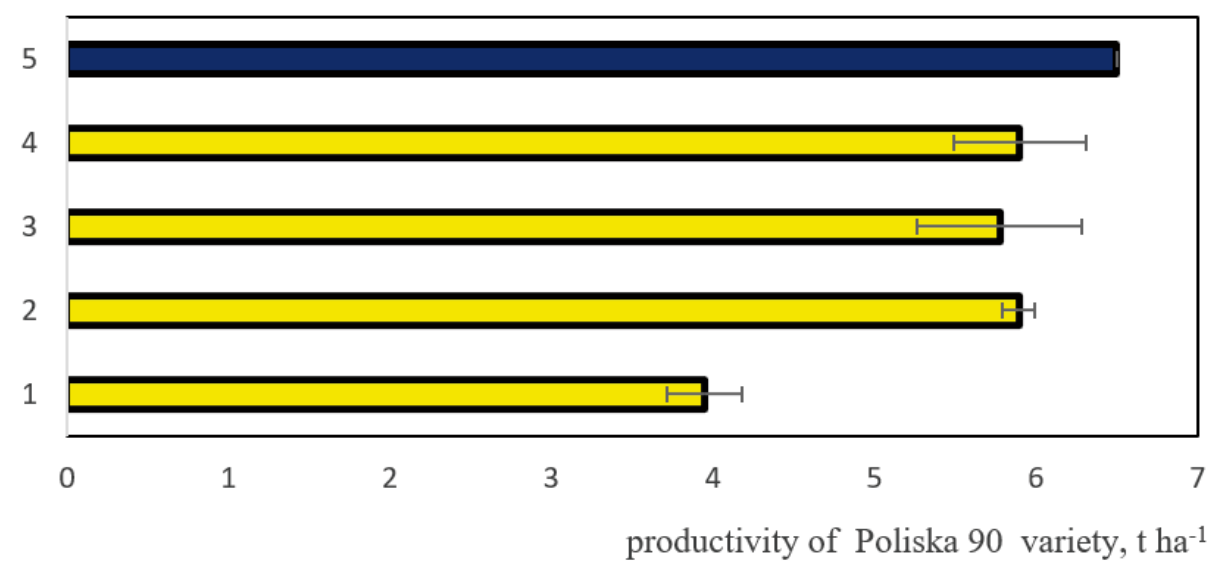

Figure 5: Influence of the technologies on productivity of winter wheat variety Poliska 90 (soil - dark grey podzolized; 1 . BT; 2. $\mathrm{BT}+\mathrm{N}_{90} \mathrm{P}_{60} \mathrm{~K}_{60} ; 3^{*}$. BT + manure $10 \mathrm{t} \mathrm{ha}^{-1} ; 4^{*}$. BT $+\mathrm{N}_{90} \mathrm{P}_{60} \mathrm{~K}_{60}+$ straw + green manure; 5. Standard) (Note: Averages in groups are significantly different from each other, ANOVA with Bonferroni correction, except of those, marked by ${ }^{\star} p<0.05$ )

gion is continental. The mean annual temperature is + $10.3^{\circ} \mathrm{C}$. The mean annual precipitation is $500-600 \mathrm{~mm}$. The basic technology and the technology that envisaged mineral fertilizers application at the rate $\mathrm{N}_{60} \mathrm{P}_{60} \mathrm{~K}_{60}$ did not ensure the implementation of biopotential of the variety. The reduction of wheat productivity in relation to the standard was $62.3-65.2 \%$. Cosequently, the influence of the technology on the state of agroecosystem by wheat productivity can be estimated as strong (Figure 4). One of the reasons could be an insufficient level of plant's supply with mobile potassium forms.

In Polissya zone, based on Rivne SARS, winter wheat of the Poliska 90 variety was studied. According to the characteristics of the variety, the potential yield of this variety is $6.5 \mathrm{t} \mathrm{ha}^{-1}$. Climate of Rivne region is continental. The mean annual temperature is $+7.8{ }^{\circ} \mathrm{C}$. The mean annual precipitation is $600-700 \mathrm{~mm}$. The actual yield level was close to the potential and achieved with the technology included mineral fertilizers application in combination with straw and green manure $\left(\mathrm{N}_{90} \mathrm{P}_{60} \mathrm{~K}_{60}+\right.$ straw + green manure $)$. The basic technology, as well as technologies that envisaged application of mineral and organic fertilizers separately, did not ensure the implementation of the variety biopotential. The deviation from the standard was 10.6-37.2 \%, the impact of technology on the agroecosystem state was moderate and average (Figure 5). It can be assumed that one of the reasons was insufficient level of plant provision with mobile potassium forms.

In Steppe zone, in the conditions of Zaporizhzhya 


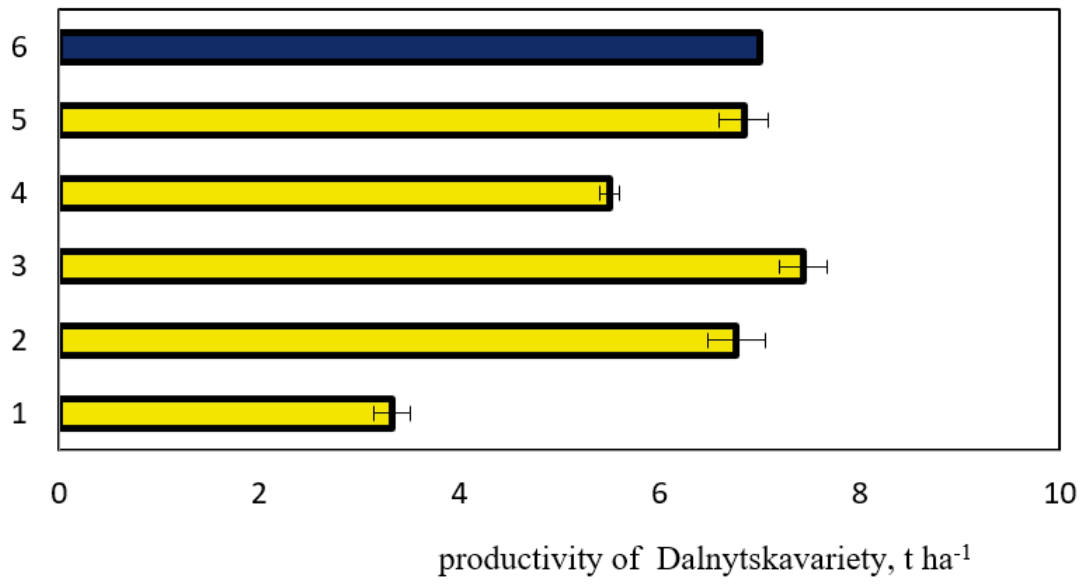

Figure 6: Influence of the technologies on productivity of winter wheat variety Dalnytska (soil - chernozem ordinary lowhumus; 1. BT; 2 . $\mathrm{BT}+\mathrm{N}_{75} \mathrm{P}_{50} \mathrm{~K}_{25} ; 3 . \mathrm{BT}+\mathrm{N}_{50} \mathrm{P}_{50} \mathrm{~K}_{50} ; 4 . \mathrm{BT}+\mathrm{N}_{15} \mathrm{P}_{10} \mathrm{~K}_{5} ; 5 . \mathrm{BT}+$ manure $5.7 \mathrm{t} \mathrm{ha}^{-1} ; 6$. Standard)

RS IOS NAAS winter wheat of the Dalnytska variety was studied. According to characteristics of the variety, the potential yield is $7 \mathrm{t} \mathrm{ha}^{-1}$. Climate of Zaporizhzhia region is continental. The mean annual temperature is + $12.8^{\circ} \mathrm{C}$. The mean annual precipitation is $430-475 \mathrm{~mm}$. The technology with mineral fertilizers application provided optimum conditions for the growth and development of plants - wheat productivity exceeded the standard and amounted to $7.56 \mathrm{t} \mathrm{ha}^{-1}$. Despite the fact that the average negative impact of this technology on nitrogen and potassium regimes of chernozem was noted, plant nutrition was balanced. At the same time, other combinations of fertilizers led to strong negative influence of the technologies on nitrogen regime of the soil and average influence on potassium regime. Consequently, the influence of these technologies can be estimated as strong and moderate according to wheat productivity (Figure 6).

Thus, it has been established that modern technologies of winter wheat growing, in most cases, do not provide plants with balanced mineral nutrition, which may be reason for the decreasing crop productivity if compared to its biological potential.

\section{CONCLUSIONS}

We recommend using a method based on identifying negative impacts of crop growing technologies on soil fertility in order to estimate ecological safety. Negative impacts of deviations from the optimum to the direction of deterioration are proposed to be grouped as follows: strong, which leads to an unsatisfactory ecological condition (>50\%), average that provides a satisfactory state $(>25 \%$, but $<50 \%)$, moderate, which provides a normal state ( $\leq 10 \%$, but $<25 \%)$, absent, an optimal condition is provided $(<10 \%)$.

It is revealed that technologies of winter wheat growing in Polissya, Forest-steppe and Steppe Zones of Ukraine can have a negative influence on potassium regime of soils; the influence by intensity can vary from moderate to strong. In Polissya and Forest-steppe, technologies of winter wheat growing can lead to deterioration of soil $\mathrm{pH}$ status. In the conditions of Steppe, along with potassium regime, the technologies can negatively influence nitrogen status and the effect may be characterized as strong.

It is shown that modern technologies of winter wheat growing, in most cases, do not provide plants with balanced nutrition, which may be one of the reasons for the low level of productivity of the crop relative to the biological potential of the variety. The decrease in productivity can fluctuate within 10.6-73.6 \%.

Modern technologies of winter wheat growing need to be improved and revised taking into account the results of ecological evaluation of their impact on soil fertility indices.

\section{REFERENCES}

Arshad, M., Martin, S. (2002). Identifying critical limits for soil quality indicators in agroecosystems. Agriculture Ecosystems \& Environment, 88(2), 153-160. https://doi. org/10.1016/S0167-8809(01)00252-3

Andrist-Rangel, Y., Edwards, A., Hillier, S., Öborn, I. (2007). Long-term $\mathrm{K}$ dynamics in organic and conventional mixed cropping systems as related to management and soil properties. Agriculture Ecosystem and Environment, 122, 413-426. https://doi.org/10.1016/j.agee.2007.02.007 Adhikari, T., Biswas, A.K., Ajay, Ramana, S., Saha, J.K., Singh, 
M.V., Kundu, S., Subba Rao, A. (2012a). Heavy metal pollution in soil-plant system and its remediation. IISS Technical Bulletin, Indian Institute of Soil Science, Bhopal, India, 1-57.

Bindraban, P.S, Stoorvogel, J.J, Jansen, D.M, Vlaming, J., Groot, J.R. (2000). Land quality indicators for sustainable land management: proposed method for yield gap and soil nutrient balance. Agriculture Ecosystem and Environment, 81, 103-112. https://doi.org/10.1016/S0167-8809(00)00184-5

Bastida, F., Zsolnay, A., Hernandez, T., Garcia, C. (2008). Past, present and future of soil quality indices: A biological perspective. Geoderma, 147(3-4), 159-171. https://doi. org/10.1016/j.geoderma.2008.08.007

Baliuk, S.A., Medvediev, V.V., Miroshnichenko, M.M., Skrylyev, E.V., Timchenko, D.O., Fateev, A.I., Khristenko, A.O., Tsapko, Yu.L. (2012). Ecological state of soils of Ukraine. Ukrainian Geographic Magazine, 2, 38-42 [in Ukrainian].

Bennett, L.T., Mele, P.M., Annett, S., Kasel, S. (2010). Examining links between soil management, soil health, and public benefits in agricultural landscapes: An Australian perspective. Agriculture Ecosystems \& Environment, 139(1-2), 1-12. https://doi.org/10.1016/j.agee.2010.06.017

Cardoso, E.J.B.N., Figueiredo Vasconcellos, R.L., Bini, D., Horta Miyauchi, M.Y., dos Santos, C.A., Lopes Alves, P.R., de Paula, A.M., Nakatani, A.S., Pereira, J.d.M., Nogueira, M.A. (2013). Soil health: looking for suitable indicators. What should be considered to assess the effects of use and management on soil health? Scientia Agricola, 70(4), 274-289. https://doi.org/10.1590/S0103-90162013000400009

Davidson, D.A. (2000). Soil quality assessment: recent advances and controversies. Progress in Environmental Science, 2, 342-350.

FAO (2003). World Agriculture: Towards 2015/2030. An FAO Perspective. FAO, Rome.

Gil-Sotres, F., Trasar-Cepeda, C., Leiros, M.C., Seoane, S. (2005). Different approaches to evaluating soil quality using biochemical properties. Soil Biology \& Biochemistry, 37(5), 877-887. https://doi.org/10.1016/j.soilbio.2004.10.003

Global Land Outlook. First Edition/ United Nations Convention to Combat Desertification (UNCCD) (2017). 336 p. Available at: https://library.unccd.int/Details/books/823

Hazrat, A., Ezzat, K., Ikram, I. (2019). Environmental Chemistry and Ecotoxicology of Hazardous Heavy Metals: Environmental Persistence, Toxicity, and Bioaccumulation. Hindawi Journal of Chemistry, Volume 2019, 1-14. https:// doi.org/10.1155/2019/6730305

IPBES (2018): The IPBES assessment report on land degradation and restoration. Montanarella, L., Scholes, R., and Brainich, A. (eds.). Secretariat of the Intergovernmental Science-Policy Platform on Biodiversity and Ecosystem Services, Bonn, Germany. 744 pages. Available at: https:// www.ipbes.net/assessment-reports/ldr

Jaskulska, I., Jaskulski, D., Kobierski, M. (2014). Effect of liming on the change of some agrochemical soil properties in a long -term fertilization experiment. Plant Soil and Environment, 60(4), 146-150. https://doi.org/10.17221/850/2013PSE
Jones, A., Ballabio, C., Fernandez, Ugalde O., Hervas, J., Lugato, E., Montanarella. L., Orgiazzi, A., Panagos, P., Paya Perez, A., Van Liedekerke, M., (2018). SOIL: how much do we value this critical resource? Highlights from recent JRC research. Ebook JRC1111081. 16 p. Available at: http://catalogue.unccd.int/1024_JRC_Soil_Highlights_eBook_0. pdf

Killebrew, K., Wolff, H. (2010). Environmental Impacts of Agriculture technologies. Evans School Policy Analysis and Research, 65, 1-18.

Karlen, D.L., Ditzler, C.A., Andrews, S.S. (2003). Soil quality: why and how? Geoderma, 114(3-4), 145-156. https://doi. org/10.1016/S0016-7061(03)00039-9

Kumar, K. and Shah, T. (2010). Available at: http://www.iwmi. cgiar.org/ iwmi-tata /files/pdf/ ground-pollute4_FULL_. pdf.

Lefebvre, A., W. Eilers, et B. Chunn (eds.). (2005). Environmental Sustainability of Canadian Agriculture: Agri-Environmental Indicator Report Series - Report 2. Agriculture and Agri-Food Canada, Ottawa, Ontario. 232 p.

Mueller, L., Schindler, U., Graham Shepherd , T., Ball , B.C., Smolentseva, E., Hu, C., Hennings , V., Schad, P., Rogasik, J., Zeitz, J., Schlindwein, S.L., Behrendt, A., Helming, K., Eulenstein, F. (2012). A framework for assessing agricultural soil quality on a global scale. Taylor \& Francis, 58, S76-S82. https://doi.org/10.1080/03650340.2012.692877

Makarenko, N.A., Bondar, V. I. (2013). Technology of crops cultivation: environmental standardization by the degree of impact over agro-ecosystem's condition. Annals of Agrarian Science, 11(4), 56-61.

Makarenko, N.A., Makarenko, V.V., Bondar, V.I. (2008). Environmental impact assessment of crop growing technologies. Agroecological magazine, Special edition, 14-17.

Makarenko, N.A., Bondar, V.I., Makarenko, V.V. (2012). Environmental inspection agro tech - guarantee sustainable development agricultural systems. Jornal of Agrucultural Sciences, 41-42. https://doi.org/10.34101/actaagrar/49/2476

Nortcliff, S. Standardisation of soil quality attributes. (2002). Agriculture Ecosystems \& Environment, 88(2), 161-168. https://doi.org/10.1016/S0167-8809(01)00253-5

Petrenko, V., Liubich, V., \& Bondar, V. (2017). Baking quality of wheat grain as influenced by agriculture systems, weather and storing conditions. Romanian agricultural research, 34, 69-76.

Puskás, I., Farsang, A. (2009). Diagnostic indicators for characterizing urban soils of Szeged, Hungary. Geoderma, 148(3-4), 267-281. https://doi.org/10.1016/j.geoderma.2008.10.014

State Standard of Ukraine. (2004). Soil quality. Soil fertility indices (Standard No. 4362) [in Ukrainian].

State Standard of Ukraine. (2002). Determination of mobile compounds of phosphorus and potassium by modified Machigin method. (Standard No. 4114) [in Ukrainian]. State Standard of Russia. (1991). Soils. Methods for determination of organic matter. (Standard No. 26213-91) [in Russian].

Shang, Y., Kamrul Hasan, Md., Golam Jalal, A., Li, M., Yin, H., Zhou, J. (2019). Applications of Nanotechnology in Plant 
Growth and Crop Protection: A Review. Molecules, 24(14), 2558. https://doi.org/10.3390/molecules24142558

Ţenu, I., Jităreanu, G., Muraru-Ionel, C., Cojocariu, P., Muraru,V. (2009). The impact of mechanization technologies on soil. Environmental Engineering and Management Journal, 8(5), 1263-1267. https://doi.org/10.30638/ eemj.2009.185

Ukraine: Soil fertility to strengthen climate resilience. Preliminary assessment of the potential benefits of conservation agriculture. Prepared under the FAO/World Bank Cooperative Programme (2014). 96p. Available at: http://www. fao.org/3/a-i3905e.pdf

United Nations Development Programme (UNDP). Combatting Land Degradation: Securing a Sustainable Future (2019). 30p. Available at: https://www.undp.org/content/ undp/en/home/librarypage/environment-energy/sus- tainable_land_management/combatting-land-degradation---securing-a-sustainable-future.html

Wasim, A. Md., Dwaipayan, S., Chowdhury A. (2009). Impact of pesticides use in agriculture: their benefits and hazards. Interdisciplinary Toxicology, 2(1), 1-12. https://doi. org/10.2478/v10102-009-0001-7

Yargholi, B., Azarneshan, S. (2014). Long-term effects of pesticides and chemical fertilizers usage on some soil properties and accumulation of heavy metals in the soil (case study of Moghan plain's (Iran) irrigation and drainage network). International Journal of Agriculture and Crop Sciences, 7(8), 518-523.

Zhou, S., Liu, J., Xu, M., Lu, J. and Sun, N. (2015). Accumulation, availability, and uptake of heavy metals in a red soil after 22-year fertilization and cropping. Environmental Science and Pollution Research, 22, 15154-15163. https:// doi.org/10.1007/s11356-015-4745-7 